\title{
Formulasi Kebijakan Hukum Pidana tentang Rehabilitas dalam Tindak Pidana Penyalahgunaan Narkotika
}

\section{Policy Formulation of Criminal Law about Rehabilitation in the Criminal Abuse of Narcotics}

\author{
Supriyadin \\ Universitas Muhammadiyah \\ E-mail: Lawyersupriyadin867@gmail.com \\ Herman \\ Pascasarjana Universitas Halu Oleo \\ E-mail: hermanmurhum2009@gmail.com \\ Handrawan \\ Pascasarjana Universitas Halu Oleo \\ E-mail: handrawansaranani84@gmail.com
}

\begin{abstract}
The article on the formulation policy of criminal law policies concerning rehabilitation in criminal acts of narcotics abuse, discussing the forms of narcotics crimes that are commonly known include, misuse exceeding dosages, drug trafficking, and buying and selling narcotics.

The problems discussed in this study are as follows: 1) Rehabilitation of Users in the legal system in Indonesia. 2) Formulation of Rehabilitation of narcotics abuse in future legal policies. This type of research is normative research. The primary legal material that is inventoried is first systematized according to the substance set by considering its relevance to the formulation of the problem and the purpose of the study.

Rehabilitation of addicts and abuse has been regulated in Article 54 in conjunction with Article 55 of the Republic of Indonesia Law Number 35 of 2009 concerning Narcotics and other supporting laws and in the case of compulsory word formulation is a reference in determining drug addicts and drug abuse must be rehabilitated. Keyword: Formulation Policy; Rehabilitation; Narcotics Crime
\end{abstract}

Abstrak: Artikel tentang formulasi kebijakan hukum pidana tentang rehabilitasi dalam tindak pidana penyalahgunaan narkotika, membahas tentang bentuk tindak pidana narkotika yang umum dikenal antara lain adalah, penyalahgunaan melebihi dosis, pengedaran narkotika, dan jual beli narkotika.

Permasalahan yang dibahas dalam penelitian ini adalah sebagai berikut: 1) Rehabilitasi Pengguna dalam sistem hukum di Indonesia. 2) Formulasi Rehabilitasi terhadap penyalahgunaan narkotika dalam kebijakan hukum yang akan datang. 
Jenis penelitian yang dilakukan adalah penelitian normatif. Bahan hukum primer yang terinventarisasi terlebih dahulu di sistematisasikan sesuai dengan substansi yang di atur dengan mempertimbangkan relevansinya terhadap rumusan masalah dan tujuan penelitian.

Rehabilitasi terhadap pecandu dan penyalahgunaan telah diatur dalam Pasal 54 jo Pasal 55 Undang-Undang Republik Indonesia Nomor 35 Tahun 2009 Tentang Narkotika dan undang-undang pendukung lainnya serta dalam hal formulasi kata wajib merupakan rujukan dalam menentukan pecandu dan penyalahgunaan narkotika harus direhabilitasi.

Kata kunci: Kebijakan Formulasi; Rehabilitasi; Tindak Pidana Narkotika

\section{PENDAHULUAN}

Menurut data Badan Narkotika Nasional (BNN), mencatat jumlah penyalahgunaan narkoba di tanah air mencapai 3,5 juta orang pada tahun 2017. Hampir 1 juta orang di antaranya telah bahkan telah menjadi pecandu, seperti yang disebutkan oleh Diah Utami sebagai berikut:

"Betapa seriusnya masalah ini. Jumlah penyalahgunaan narkoba di Indonesia diperkirakan telah mencapai sekitar 3,5 juta orang pada tahun 2017, dimana 1,4 juta Adalah pengguna biasa dan hampir satu juta telah menjadi pecandu narkoba, Selain itu lanjutnya ada lebih dari 12 ribu kematian terkait narkoba setiap tahunnya, hal ini tidak hanya merugikan Negara baik dari sisi ekonomi dan sosial. Pembuat penyelundup dan penyalahgunaan narkotika terus berlanjut Dan tumbuh diindonesia. Hal ini menciptakan sejumlah dampak negatif meliputi ekonomi, kesehatan, sosial, dan generasi muda. Saat ini peredaran narkoba semakin mengkhawatirkan. Data BNN obat terlarang ini tidak hanya beredar di kota besar. Daerah terpencil pun sudah ternodai oleh benda ilegal tersebut." 1

Berdasarkan isi ketentuan Pasal 54 jo. Pasal 55 Undang-Undang Republik Indonesia Nomor 35 Tahun 2009 tentang Narkotika telah adanya kata mewajibkan bagi pengguna atau penyalahgunaan narkotika harus rehabilitasi namun faktanya masih banyak yang divonis dengan ancaman penjara.

Sehingga dalam hal ini memang diperlukan suatu formulasi hukum mengenai penerapan dan pemberian rehabilitasi sebagai mana yang diamanahkan dalam Pasal 54 jo. Pasal 55 Undang-Undang Republik Indonesia Nomor 35 Tahun 2009 Tentang Narkotika.

Berdasarkan uraian di atas di satu sisi pelaku penyalahgunaan narkotika merupakan suatu tindak kejahatan dan pelaku tindak pidana tersebut harus dihukum yaitu dengan pidana penjara karena menggunakan narkotika dengan tanpa hak dan

\footnotetext{
1 Muhammad Radityo Priyasmoro, BNN: Pemakai Narkoba di Indonesia Capai 3,5 Juta Orang pada 2017, Liputan6, https://www.liputan6.com/news/read/3570000/bnn-pemakai-narkoba-di-indonesia-capai35-juta-orang-pada-2017, 26 Juni 2018, diakses pada tanggal 9 Februari 2019.
} 
melawan hukum. Namun di sisi lain juga merupakan korban dari tindak pidana yang dilakukan oleh dirinya sendiri karena adanya dorongan untuk menggunakan narkotika secara terus menerus dengan takaran yang terus meningkat agar menghasilkan efek yang sama dan apabila penggunaannya dikurangi dan/atau dihentikan secara tiba-tiba akan menimbulkan gejala fisik dan psikis yang khas.

Berdasarkan fenomena yang telah dijelaskan di atas, maka permasalahan yang diangkat oleh penulis untuk dibahas adalah "Formulasi Kebijakan Hukum Pidana Tentang Rehabilitasi Dalam Tindak Pidana Penyalahgunaan Narkotika”.

\section{ANALISIS DAN PEMBAHASAN}

\section{Rehabilitasi Pengguna Dalam Sistem Hukum di Indonesia}

Dalam pasal 54 Undang-Undang RI Nomor 35 Tahun 2009 tentang Narkotika diatur bahwa pecandu dan korban penyalahgunaan narkotika wajib menjalani rehabilitasi medis dan rehabilitasi sosial. Berdasarkan penjelasan Pasal 45 Undang-Undang RI Nomor 35 Tahun 2009 tentang Narkotika disebut bahwa yang dimaksud dengan pecandu narkotika adalah orang yang menggunakan atau menyalahgunakan narkotika dalam keadaan ketergantungan, sedang yang dimaksud dengan korban penyalahgunaan narkotika adalah seseorang yang tidak sengaja menggunakan narkotika karena dibujuk, diperdaya, ditipu, dipaksa, dan dipaksa untuk menggunakan narkotika.

Terus meningkatnya jumlah korban penyalahgunaan narkotika membuat peran terapi dan rehabilitasi bagi korban narkotika menjadi penting dan strategis. Untuk itu bidang terapi dan rehabilitasi diminta untuk proaktif terus mencari terobosan agar perannya menjadi efektif.

Saat ini banyak pecandu Narkotika yang tertangkap lagi oleh aparat kepolisian setelah menjalani masa hukuman di penjara. Salah satu alasannya adalah tidak dapat lepas dari ketergantungan terhadap Narkotika dan terpaksa kembali menyalahgunakan Narkotika. Sehingga pemidanaan dengan pidana penjara tidaklah efektif untuk menjerakan pecandu Narkotika. Oleh karena itu, Rehabilitasi dianggap sebagai pemidanaan yang lebih tepat untuk menanggulangi penyalahgunaan Narkotika".2 Ketentuan Hakim dalam menjatuhkan putusan tindakan Rehabilitasi bagi terdakwa

\footnotetext{
2 Jahid Hanafi, Pertimbangan Hakim Dalam Menjatuhkan Putusan Tindak Pidana Pecandu Narkotika, Skripsi, Yogyakarta: Universitas Islam Negeri Kalijaga, 2013, hlm. 29.
} 
Penyalahgunaan Narkotika terdapat dalam Pasal 54, Pasal 55 dan Pasal 103 UndangUndang Republik Indonesia Nomor 35 tahun 2009 Tentang Narkotika.

Yang menjadi syarat atau ketentuan dalam menjatuhkan tindakan rehabilitasi hakim berpendapat bahwa harus memenuhi beberapa ketentuan di antaranya sebagai berikut:

(1) Kalau terdakwa diputus dengan pidana penjara maka terdakwa tidak dapat menjalani pengobatan atau rehabilitasi hal tersebut yang menjadikan terdakwa semakin kecanduan terhadap Narkotika;

(2) Pernah menjalani pengobatan atau rehabilitasi untuk menyembuhkan kecanduan terhadap Narkotika;

(3) Adanya surat pernyataan atau assesment dari dokter ahli yang menangani terdakwa;

(4) Adanya keterangan ahli dari dokter ahli yang dapat dijadikan petunjuk oleh hakim untuk memutus tindakan rehabilitasi."3

Menurut penulis Pasal 54, Pasal 55, Pasal 103 dan Pasal 127 Undang-Undang Republik Indonesia Nomor 35 Tahun 2009 dan Surat Edaran Mahkamah Agung tentang Penempatan Penyalahgunaan, Korban Penyalahgunaan dan Pecandu Narkotika ke dalam Lembaga Rehabilitasi Medis dan Rehabilitasi Sosial Nomor 04 Tahun 2010 ini merupakan dasar hakim dalam menjatuhkan putusan tindakan rehabilitasi bagi terdakwa. Putusan tindakan rehabilitasi dapat di berikan apabila ada keterangan dari dokter ahli yang memeriksa atau menangani terdakwa dan dengan keterangan dari dokter ahli tersebut hakim dapat mendapatkan petunjuk yang nantinya akan menjadi salah satu dasar di putuskannya tindakan rehabilitasi bagi terdakwa dan hukuman yang dijatuhkan kepada terdakwa ini tidak harus berupa penjatuhan hukuman pidana atau tahanan semata. Akan tetapi juga lebih memperhatikan masalah penyembuhan rasa kecanduan dari diri terdakwa. Jika semata-mata ingin menghukum si terdakwa dengan pidana penjara bukan tidak mungkin jika terdakwa setelah keluar dari penjara akan melakukan perbuatan penyalahgunaan Narkotika lagi.

Batasan barang bukti yang ada pada tersangka, BNNP juga mengacu pada SEMA No. 4 Tahun 2010, yaitu maksimal 5 gram. SEMA tersebut merupakan surat yang menjadi

3 Wawancara Pribadi Rudi Suparmono, Ketua Pengadilan Negeri Kendari, 4 Maret 2019, Pukul 10.30 WIB. 
arahan dan acuan bagi hakim pengadilan negeri dan hakim pengadilan tinggi dalam memutus perkara pecandu narkotika yang tertangkap tangan untuk dapat dijatuhi pidana berupa tindakan rehabilitasi seperti yang diatur dalam Pasal 103 Undang-Undang Republik Indonesia Nomor 35 Tahun 2009 tentang Narkotika.

Bisa kita melihat maraknya pengguna narkotika dimana-mana bahkan ancaman hukuman yang diancamankan bagi pelaku penyalahgunaan narkotika bisa diancam hukuman mati namun hal tersebut tidak membuat efek jerah terhadap pelaku bahkan pengguna atau penyalahgunaan semakin bertambah.

Menurut data Badan Narkotika Nasional (BNN), mencatat jumlah penyalahgunaan narkoba di tanah air mencapai 3,5 juta orang pada tahun 2017. hampir 1 juta orang di antaranya telah bahkan telah menjadi pecandu. Demikian data dari hasil penelitian Badan Narkotika Nasional (BNN) dan Puslitkes UI pada 2017. Sekitar 1,77\% atau 3,3 juta penduduk Indonesia menjadi penyalahgunaan narkoba. ${ }^{4}$

Sehingga penulis melihat masalah narkotika saat ini merupakan ancaman yang serius bagi bangsa ini, hal tersebut bukanlah sesuatu yang harus dikesampingkan dalam penerapan hukum tidak hanya sebagai pembalasan saja namun juga harus memperhatikan asas manfaat dalam penerapan hukumnya maksud dari penulis Adalah bahwa dalam memutuskan suatu perkara harus memperhatikan sisi kemanfaatan penerapan hukumnya yakni bagaimana pelaku penyalahgunaan narkotika ini bisa diterima kembali dimasyarakat dan sembuh dari ketergantungan obat terlarang tersebut.

Hal tersebut sejalan dengan teori pemidanaan yakni Teori Tujuan/Relatif Pada penganut teori ini memandang sebagaimana sesuatu yang dapat digunakan untuk mencapai pemanfaatan, baik yang berkaitan dengan orang yang bersalah maupun yang berkaitan dengan dunia luar, misalnya dengan mengisolasi dan memperbaiki penjahat atau mencegah penjahat potensial, Akan menjadikan dunia tempat yang lebih baik. ${ }^{5}$

Sehingga penulis melihat tujuan hukum itu tidak semata-mata untuk memberikan penghukuman berupah penjara namun yang utama adalah bagaimana pelaku dapat sembuh dan bisa beradaptasi kembali dengan masyarakat ketika keluar dari masalah hukum, dimana konsep ini sejalan dengan tujuan dari pada pembinaan para terpidana dilembaga pemasyarakatan dan tujuan hukum yang akan datang dimana pelaku kejahatan

\footnotetext{
4 Investor Daily Indonesia, Pengguna Narkoba Capai 1,77\% Penduduk, Kerugian Rp 84,7 Triliun, Investor Daily Indonesia, https://investor.id/archive/pengguna-narkoba-capai-177-penduduk-kerugian-rp-847triliun, 19 Maret 2018, diakses pada tanggal 9 Februari 2019.

5 Muladi. Lembaga Pidana Bersyarat. Bandung: Alumni. 2002, hlm 51.
} 
tidak harus menjalani hukuman berupah penjara namun bagaimana pelaku kejahatan ini tidak mengulangi kejahatan itu yakni dengan memperhatikan asas manfaat bagi pelaku kejahatan berupah pemberian rehabilitasi bagi penyalahgunaan narkotika.

Tentunya menurut penulis dengan memberikan rehabilitasi kepada pengguna narkotika Adalah langkah yang tepat dibandingkan menghukum dengan berupa pemenjaraan sebab dengan menghukum melalui pemenjaraan pelaku tidak akan sembuh dari ketergantungan dalam menggunakan narkotika dikemudian hari serta ketika kembali ke masyarakat dapat menjalankan aktivitas seperti biasa tanpa merasa tertekan dengan perbuatan kejahatan yang dilakukan sebelumnya.

\section{Formulasi Rehabilitasi Terhadap Penyalahgunaan Narkotika dalam Kebijakan Hukum yang Akan Datang}

Banyak kasus narkotika yang diputus oleh hakim dengan penjatuhan sanksi pidana penjara atau kurungan. Sementara dalam undang-undang yang berlaku sekarang yakni Undang-Undang No. 35 Tahun 2009 Tentang Narkotika ditegaskan bahwa adanya rehabilitasi terhadap penyalahgunaan narkotika terdapat dalam Pasal 54. Berdasarkan pasal ini rehabilitasi dapat diselenggarakan oleh instansi pemerintah atau masyarakat yang di atur dalam peraturan menteri.

Dalam praktiknya penerapan pidana bagi penyalahgunaan narkotika sering terjadi, bisa kita melihat salah satu putusan dari sekian banyaknya putusan pidana bagi pengguna narkotika yaitu putusan perkara narkotika nomor 608/Pid.Sus/2017/PnTrg, pada hari Kamis tanggal 16 November 2017 di Pengadilan Negeri Tengarong. Sebaliknya dengan membandingkan putusan perkara narkotika nomor 79/Pid/2012/PT.TK. pada tanggal 6 Juli 2012.

Sehingga dalam memutuskan perkara harus memerhatikan kata "wajib" di dalam pasal 54 jo. 55 Undang-Undang Republik Indonesia Nomor 35 tahun 2009 tentang narkotika. Kata wajib tersebut sangat jelas tidak ada pemaknaan lain selain kata harus dilakukan atau dilaksanakan tanpa ada alasan lain lagi.

Kata wajib menurut Kamus Besar Bahasa Indonesia (KBBI) adalah:

1. harus dilakukan; tidak boleh tidak dilaksanakan (ditinggalkan) dan 
2. sudah semestinya; harus. $^{6}$

Dengan demikian maka sudah seharusnya pelaku atau pecandu narkotika itu direhabilitasi dan juga memang penting adanya sebuah formulasi baru terkait penerapan rehabilitasi bagi pengguna narkotika bukan sekadar pengobatan medis atau sosial saja namun perlu diperhatikan juga terhadap proses penerapan penyembuhan secara total agar tidak mengulangi lagi perbuatan itu, sehingga formulasi ini sangat penting guna tercapainya tujuan rehabilitasi yang diharapkan dimasa yang akan datang. yakni berupa:

\section{Kecenderungan Pasal yang Digunakan Pemidanaan Bagi Pengguna Narkotika Harus Diubah}

Dalam penerapannya, terdapat beberapa pasal dalam Undang-Undang Republik Indonesia Nomor 35 Tahun 2009 Tentang Narkotika yang sering dikenakan oleh Penuntut Umum, baik dalam dakwaan maupun tuntutan. Mulai dari Pasal 111, Pasal 112, Pasal 114, dan Pasal 127 Undang-Undang Republik Indonesia Nomor 35 Tahun 2009 Tentang Narkotika. Kecenderungan penggunaan pasal dan cara perumusan dakwaan dengan dakwaan subsidiaritas ini membawa pengaruh yang signifikan terhadap penempatan seorang pengguna narkotika di lembaga rehabilitasi baik medis maupun sosial. Berikut adalah beberapa pasal yang cenderung digunakan. Pasal 111 ayat (1) Undang-Undang Republik Indonesia Nomor 35 Tahun 2009 Tentang Narkotika, perbedaannya dengan Pasal 112 ayat (1) Undang-Undang Republik Indonesia Nomor 35 Tahun 2009 Tentang Narkotika adalah pada bentuk narkotikanya, yaitu berbentuk tanaman atau bukan tanaman. Lalu, Pasal 114 ayat (1) Undang-Undang Republik Indonesia Nomor 35 Tahun 2009 Tentang Narkotika.

Menurut penulis Ketiga pasal tersebut cenderung ditempatkan dalam dakwaan primer. Selain unsur-unsurnya lebih luas dan peluang menjerat pelaku semakin besar, hal ini juga membawa konsekuensi kepada tertutupnya kemungkinan bagi pengguna narkotika untuk ditempatkan dalam lembaga rehabilitasi medis maupun sosial.

Berbeda halnya apabila pasal yang cenderung diterapkan dalam dakwaan primer adalah Pasal 127 (3)Narkotika. Pasal tersebut merupakan satu kesatuan dengan Pasal 127 ayat (2) Undang-Undang Republik Indonesia Nomor 35 Tahun 2009 Tentang Narkotika yang menyatakan bahwa dalam memutus perkara sebagaimana dimaksud pada ayat (1), hakim

\footnotetext{
6 Badan Pengembangan dan Pembinaan Bahasa, Wajib, KBBI Daring https://kbbi.kemdikbud.go.id/entri/ Wajib, diakses pada tanggal 9 Februari 2019.
} 
wajib memperhatikan ketentuan sebagaimana dimaksud dalam Pasal 54, Pasal 55, dan Pasal 103 Undang-Undang Republik Indonesia Nomor 35 Tahun 2009 Tentang Narkotika. Pasal-pasal tersebut mewajibkan dan memberikan pedoman bagi hakim untuk menempatkan pengguna narkotika ke dalam lembaga rehabilitasi medis dan sosial.

Dari kecenderungan formulasi pasal dakwaan yang digunakan oleh Penuntut Umum tersebut dapat dikatakan bahwa pendekatan pemidanaan penjara terhadap pengguna narkotika lebih dominan dibandingkan dengan menempatkan pengguna dalam lembaga rehabilitasi baik secara medis maupun sosial.

Selain itu, kecenderungan pengenaan Pasal 111, Pasal 112, dan Pasal 114 Undang-Undang Republik Indonesia Nomor 35 Tahun 2009 Tentang Narkotika juga membawa imbas yang cukup besar bagi penahanan terhadap pengguna narkotika. Ancaman pidana pada Pasal 111 dan Pasal 112 Undang-Undang Republik Indonesia Nomor 35 Tahun 2009 Tentang Narkotika yang minimum 4 (empat) tahun serta maksimum 12 (dua belas) tahun sementara Pasal 114 dengan ancaman pidana minimum 5 (lima) tahun dan maksimum 20 (dua puluh) tahun menyebabkan penahanan terhadap pengguna narkotika dilakukan karena sudah memenuhi unsur obyektif.

Selanjutnya adalah mengenai perumusan pasal yang sangat longgar dalam Pasal 111 dan Pasal 112 Undang-Undang Republik Indonesia Nomor 35 Tahun 2009 Tentang Narkotika. Perumusan yang demikian bertentangan dengan prinsip lex certa dan lex stricta yang merupakan turunan dari prinsip negara hukum. Kedua pasal tersebut tidak dapat membedakan antara pengguna narkotika dan bukan pengguna narkotika.

\section{Formulasi Perumusan Sanksi Pidana Harus Diperbaiki Lagi}

Dari sisi formulasi perumusan sanksi pidana dalam Undang-Undang Republik Indonesia Nomor 35 Tahun 2009 Tentang Narkotika, ditemukan beberapa bentuk perumusan sanksi pidana. Secara garis besar, dalam Undang-Undang Republik Indonesia Nomor 35 Tahun 2009 Tentang Narkotika, perumusan sanksi pidana meliputi perumusan secara tunggal, kumulatif, alternatif, dan kumulatif-alternatif.

Sistem perumusan sanksi pidana secara tunggal adalah sistem perumusan yang hanya memuat satu jenis pemidanaan. Hal ini dapat terlihat pada Pasal 127 ayat (1) Undang-Undang Republik Indonesia Nomor 35 Tahun 2009 Tentang Narkotika.

Sistem perumusan sanksi pidana yang kedua adalah perumusan secara kumulatif, dimana berarti perumusan dilakukan dengan cara menggabungkan beberapa jenis 
pemidanaan. Misalnya, pidana penjara dan pidana denda. Dalam Undang-Undang Republik Indonesia Nomor 35 Tahun 2009 Tentang Narkotika, hal tersebut dapat dilihat pada Pasal 126 ayat (1) Undang-Undang Republik Indonesia Nomor 35 Tahun 2009 Tentang Narkotika. Pasal 126 ayat (1) Undang-Undang Republik Indonesia Nomor 35 Tahun 2009 Tentang Narkotika.

Sistem perumusan sanksi pidana berikutnya adalah perumusan secara alternatif dimana sistem perumusan tersebut memberikan alternatif jenis pemidanaan yang akan digunakan oleh penuntut umum dalam merumuskan tuntutan atau memberikan alternatif bagi hakim untuk menjatuhkan putusan. Misalnya, pidana penjara atau denda. Dalam Undang-Undang Republik Indonesia Nomor 35 Tahun 2009 Tentang Narkotika, perumusan tersebut dapat dilihat pada Pasal 128 (1) Undang-Undang Republik Indonesia Nomor 35 Tahun 2009 Tentang Narkotika.

\section{KESIMPULAN}

Rehabilitasi terhadap pecandu dan penyalahgunaan telah diatur dalam Pasal 54 jo. Pasal 55 Undang-Undang Republik Indonesia Nomor 35 Tahun 2009 tentang Narkotika dan Undang-Undang pendukung lainnya serta dalam hal formulasi kata wajib merupakan rujukan dalam menentukan pecandu dan penyalahgunaan narkotika harus direhabilitasi.

\section{Daftar Pustaka}

\section{Buku}

Muladi. Lembaga Pidana Bersyarat. Bandung: Alumni. 2002.

Hanafi, Jahid. Pertimbangan Hakim Dalam Menjatuhkan Putusan Tindak Pidana Pecandu Narkotika, Skripsi, Yogyakarta: Universitas Islam Negeri Kalijaga. 2013.

\section{Peraturan Perundang-undangan}

Undang-Undang Republik Indonesia Nomor 35 Tahun 2009 tentang Narkotika

\section{Situs Internet}

Badan Pengembangan dan Pembinaan Bahasa, Wajib, KBBI Daring https://kbbi.kemdikbud.go.id/entri/Wajib, diakses pada tanggal 9 Februari 2019. Investor Daily Indonesia, Pengguna Narkoba Capai 1,77\% Penduduk, Kerugian Rp 84,7 Triliun, Investor Daily Indonesia, https://investor.id/archive/pengguna-narkoba- 
capai-177-penduduk-kerugian-rp-847-triliun, 19 Maret 2018, diakses pada tanggal 9 Februari 2019.

Priyasmoro, Muhammad Radityo, BNN: Pemakai Narkoba di Indonesia Capai 3,5 Juta Orang pada 2017, Liputan6, https://www.liputan6.com/news/read/3570000/bnnpemakai-narkoba-di-indonesia-capai-35-juta-orang-pada-2017, 26 Juni 2018, diakses pada tanggal 9 Februari 2019. 